\title{
Research on the Reasonable Strategy of the Development of Commercial Banks under the Perspective of P2P Internet Financial Risks
}

\author{
LI Liqin ${ }^{1}$ \\ ${ }^{1}$ Xi'an International University, \\ Xi'an 710077,China
}

\begin{abstract}
In this paper, we conduct research on the reasonable strategy of the development of commercial banks under the perspective of $\mathrm{P} 2 \mathrm{P}$ Internet financial risks. $\mathrm{P} 2 \mathrm{P}$ financial model mainly for China's small and medium enterprises and individuals to provides financing services. Generally need to use e-commerce professional network platform lending to help both sides to establish lending relationship and complete the related formalities. Traditional commercial banks need reform to keep up with the novel financial tools related to the Internet financing which will be discussed below.
\end{abstract}

Keywords: Reasonable Strategy; Commercial Banks; P2P Internet Financial; Risk Measurement.

\section{Introduction}

After years of development, Internet companies stay in business does not provide technical support to financial institutions and service level, the data accumulated through the depth of mining information, to expand our business to the financial sector, build financial models and Internet become the emerging field of combining information technology and capital. Internet financial model is different from indirect financing of commercial bank, also is different from direct financing capital market's third financial financing model. From the perspective of the financing mode of Internet financial mode in essence is a kind of direct financing mode. But compared with the traditional mode of direct financing, Internet financing model has a large amount of information, lower transaction costs, high efficiency, etc. We believe that the Internet finance is based on modern information technology for financial activities, with functions of financing, payment and transaction intermediary. Internet financial is pushing Banks to prepare early. If hope the Internet financial thrive, and ensure that commercial banks can continue to become bigger and stronger, at the same time also requires China's market economy more and more prosperous, then discusses the Internet banking and commercial Banks to maintain what kind of relationship, achieve a the double win situation is very necessary. Internet financial and commercial banks are financial services, business, competition is inevitable, but it is not a zero-sum game and the two are not can't live together. Internet financial by low cost, innovative business mode to promote the realization of the financial, improve small micro financing covered and covered in financial investment, reduce the financial transaction costs. Development course is short but it tough situation, the reason is that financial markets are highly regulated, the limitation of the commercial bank service and the existence of the financial innovation supervision blind area makes Internet financial "need for persons" and in the face of the Internet financial menacing, commercial banks are taking measures to actively respond to. Internet financial is reversed transmission commercial bank reform and innovation.

Networking financial role in promoting development of commercial banks could be summarized as the follows. (1) Internet financial products rich investment channels, also brought a certain degree of customer loss to commercial banks, commercial banks began to take the initiative to search the new path of combined 
with Internet technology. (2) Commercial Banks also standardized the management of the Internet industry and think that the Internet companies should follow strict limits on banking law, fair competition with banks. Actually wealth-management business competition will not be the root of the leveraged bank profits, but the impact can improve the uncertainty of future sustainable profitability. (3) Internet financial financing model to better meet the demand for credit of micro, small and medium enterprises, inspired by the commercial Banks to restore lending patterns. Commercial banks are the participants of the market economy, preference for high credit rating, assets large state-owned enterprises to conform to the requirements of the credit risk management. Micro, small and medium enterprises has the characteristics of frequent turnover and default risk big, at the request of the control of non-performing loans, commercial banks to lend to enterprises to conduct a comprehensive due diligence, mortgage lending, the process is very complicated. P2P lending patterns can inspire a bank to use the "big data" to build a credit rating model and credit evaluation method of reference P2P platform will increase small micro loan proportion which will improve the efficiency of capital allocation. (4) Third-party payment to form instead of the intermediary business of commercial Banks, forcing commercial banks to lower service price, to improve the unreasonable pricing. Although the new regulations will affect the banks' profits in the short term, but the long term will help banks improve the level of service, enhance profitability, this is clearly the Internet financial proof reversed transmission banking reform.

To deal with the mentioned challenges, in this paper, we conduct research on the reasonable strategy of the development of commercial banks under the perspective of $\mathrm{P} 2 \mathrm{P}$ Internet financial risks. $\mathrm{P} 2 \mathrm{P}$ financial model mainly for China's small and medium enterprises and individuals to provides financing services. Generally need to use e-commerce professional network platform lending to help both sides to establish lending relationship and complete the related formalities. Borrowers can release loan information, including reimbursement means and time, amount, interest, realize self-help borrowing. Lenders information released by the borrower, the loan amount decided for ourselves to realize self-help borrowing. To enhance the competitiveness of the traditional commercial bank, we will discuss the suggestions and solutions in the following sections.

\section{The Proposed Methodology and Strategy}

The Principles of P2P Financial Pattern. $\mathrm{P} 2 \mathrm{P}$ lending patterns originated in the United States, the prevailing in European and American countries, constantly committed to using this new type of financing for small and medium enterprises financial model and personal lending play a positive role in promoting. In our country, the P2P model is in its infancy, but its development is swift and violent. Comprehensive, the cause and development of the P2P financial is mainly due to the fast and rapid development of Internet technology and the urgent need of small business financing problems. Peer-to-peer network as a loan borrowers and investors of the network platform and completed the money supply and the demand of intermediary role. In the bank financial products and innovation conference pointed out that: in the network financial development innovation at the same time, P2P network loans should be accurate positioning service nature and scope, but the current lack of regulatory mechanisms such as, making the development of the P2P network is borrowed a discordant note. The following parts describe the primary risks for the $\mathrm{P} 2 \mathrm{P}$ financing.

(1) Individual network platform alleged illegal financing loan. P2P network credit in our country only a few years' time, all aspects of supervision, supervision and credit collection mechanism is not perfect, and reveal some 
loopholes in management rules, and appear the phenomenon such as alleged illegal financing. (2) Some borrowers more than pretend to be not practical borrowers identity and absorbing funds, under high returns to lure investors to raise money for personal consumption, even will risk transfer to the investors and the $\mathrm{P} 2 \mathrm{P}$ network platform, some will absorb the funds in the form of usury out earn price difference, some borrowers appear even hold a run phenomenon, thus indirectly contributed to illegal financing. (3) Capital risk. Investors put money in net credit platform looking for a partner, a $\mathrm{P} 2 \mathrm{P}$ network credit company does not have to open the third party hosting platform, even open a third party escrow platform, the use of funds on the third party to the lack of regulation, treat this money network platform as its own funds can use loan, divert, cannot effectively control risk, eventually passed on to investors, if not timely return, the net credit platform collapse or boss run phenomenon. (4) Network technology management. With the progress of information technology, more and more threats and has also created new problems, such as hackers and virus invades affects the stable operation of the platform, the formation of financial information, customer information confidential. Managers or lack of maintenance consciousness from the perspective of "saving" cost reducing maintenance costs, and follow-up of network platform technology often cannot receive timely or perfect solution, and therefore there is a potential safety hazard and stable in operation and cause greater economic losses which will be dangerous [1-2].

The Core Competitiveness of the Traditional Banks. With the rapid development of Internet financial also cannot leave the support of commercial banks. First of all, it is the development of commercial banks is not perfect for Internet financial business development space and opportunities. Secondly, the design of the Internet financial products is attached to the traditional commercial banks. Commercial banks to support Internet financial risk control ability to ascend. The vast majority of micro, small and medium enterprises, individuals, not on the official credit system for the record and this is also one of the reasons for their financing difficulties [3-4]. As in the financial system of social credit value's biggest bank, risk prevention consciousness is very strong. When the Internet financial began to rise, harvest a lot of customers and traffic, the most urgent task is to refine maintenance platform risk and value. Therefore, the integration of commercial bank credit considerations method can less roundabout way, learning for examination and assessment of commercial bank credit.

Commercial banks involved in monitoring the Internet financial liquidity risk. Financial markets claims that "cash is king", any a commercial bank can't afford to run. For commercial banks to build the risk reserve, interbank lending and the bank risk prevention and control system composed of as a last resort. And complex Internet financial product design novel, many varieties, the lack of historical data reference, is difficult to predict the future cash flow, and no pressure test, scene simulation, rigid wind control requirements, combined with the risk of transmission speed is quicker than the traditional industry and is wider, so in case of extreme events, easy to cause liquidity risk, jeopardizing the interests of investors, confidence in the emerging financial pattern, and even spread to commercial banks, increase the difficulty of liquidity risk management. So commercial banks of cooperation of Internet financial enterprises provide risk disclosure and monitoring which is the equivalent to the Internet sharing financial risk management experience, help to reduce the liquidity risk of Internet finance, but also to the whole financial market orderly.

The Characteristics of Internet financing. In the Internet in the financial markets, financial transactions possibility boundary greatly expand and transaction costs may appear sharply, financial democratization the characteristics 
fully revealed. Internet financial innovation, the biggest characteristic is that the financial and non-financial elements bundled together, blurred the line between financial and nonfinancial products. Internet financial is not a simple application of Internet technology in the financial industry, but the Internet industry and financial industry. This integration on the one hand, provides a new investment channels for domestic investors, on the other hand also to solve the problem of small micro enterprise financing difficulties provides a train of thought. However, the rise of the Internet financial also puts forward new challenge on the macro financial stability. At present, financial regulators on the regulation of the Internet financial enterprise ideas did not agree, the Internet financial enterprises in the case of the lack of regulatory constraints are savage growth, resulting in the Internet financial enterprise itself to gather up the bigger risk.

Small micro enterprise financing difficult problem is widespread, people began to explore various financing innovation model to solve this difficult problem. The vigorous development of e-commerce for electrical business and financial institutions has to see the business opportunities and developed based on e-commerce transaction platform of Internet financial management mode innovation. Financing model of the novel ecommerce trading platform independent structurally changed the traditional financial institutions to small micro enterprise financing loans, using information, network transaction platform to support the credit reporting systems into a credit history, more in line with the small micro enterprise financing characteristics and requirements. The emergence of the Internet financial increased competition between financial institutions, forcing the financial institutions to enhance the basic function and efficiency so as to adapt to competition. This aspect can improve the efficiency of financial institutions to provide financing for the enterprise and on the other hand can reduce the financing cost of enterprises in the financial markets. Enterprise financing efficiency and lower funding costs could prompt companies to increase their output, and then promote the overall economic growth and therefore, the combination is urgently needed for the enterprises.

The Combination of Commercial Banks and Internet Finance. With the rapid development of Internet financial in our country has its objective basis. Compared with the traditional banking is more flexible and convenient to refinance promoted the development of the real economy, especially the small micro enterprise credit financing difficulty relief to promote its development and share the profits. Internet financial impact for the traditional banking, but will not damage the system, also has not changed the nature of the financial, but rather to promote its transformation, accelerate the innovation and provide differentiated services which make the whole financial system more hasten is diverse, the future or the Internet finance and the depth of the fusion of traditional banking.

Financial regulation for the overall safety of the financial system, support the development of the real economy. The emergence of the Internet financial products to promote the general progress of interest rate marketization essence, and the financial product innovation also puts forward higher requirements for financial regulation, on the premise of preventing risks, financial innovation should be encouraged. The purpose of regulation should be positioned to provide a clear and transparent legal environment, the result should be standardize market healthy operation, and should not be to contain the financial innovation, reduce the financial efficiency and should also avoid the regulatory injustice, eliminate regulatory arbitrage opportunities. The development of the information is the core of the financial, commercial banks also inseparable from the strong support of information technology. Therefore, commercial banks to increase investment in science and technology, and the 
depth of the excavation user data, strengthen the security of credit information and convert the information in the long-term commercial banks accumulate into a competitive advantage.

\section{Conclusion}

In this paper, we conduct research on the reasonable strategy of the development of commercial banks under the perspective of $\mathrm{P} 2 \mathrm{P}$ Internet financial risks. P2P network to borrow most of the participants for the small micro enterprises and individuals, the development of $\mathrm{P} 2 \mathrm{P}$, requires a reliable complete credit system as support, this requires that there must be a lot of data as support. Financial market supply and demand imbalances create an opportunity for the emergence of the Internet financial. Finally, the emergence of the Internet financial is a spirit of the Internet to the result of the financial sector. Face the challenges, the traditional financial institutions also speed up the financial services of the Internet. In our research, we analyzed the corresponding issues in detail.

\section{Acknowledgement}

This paper is supported by the soft science research plan on the project in Shaanxi province (NO. 2015KRM160). The project name is: the development of commercial banks under the background of Internet financial strategy research using the bank of China Shaanxi branch as the example.

\section{References}

[1] Chen H Q. Innovative Development of Commercial Banks in the Internet Financial Background $[\mathrm{J}]$. Journal of Ningbo University, 2014.

[2] Feng H X, Cui J X, Gui-Hua H U. Risks and Countermeasures on Development of Logistics Financial Services for Commercial Banks[J]. Logistics Engineering \& Management, 2012.

[3] Dai G Q, Fang P F. The Liberalization of Interest Rate and the Risks of Bank-A Study from the Perspective of Shadow Banking and Internet Finance $[\mathrm{J}]$. Finance Forum, 2014.

[4] Feld S, Sch02nfeld M, Werner M. Analyzing the Deployment of Bitcoin's P2P Network under an AS-level Perspective [J]. Procedia Computer Science, 2014:1121 1126. 